\title{
КАДРИ УПРАВЛІННЯ НКВС В ОДЕСЬКІЙ ОБЛАСТІ В РОКИ ВЕЛИКОГО ТЕРОРУ: «САНАЦІЯ» ПАРТІЙНИМИ ОРГАНАМИ
}

Анотація: У статті йдеться про кадрову політику ВКП(б) в органах НКВС наприкінці 30-х років XX ст. з екстраполяиією на УНКВС в Одеській області. На основі малознаних архівних джерел партійного походження з Державного архіву Одеської області (ДАОО) здійснено дослідження стосовно представників першої ланки, «низового ешелону» управлінь НКВС: співробітників районних відділів, оперуповноважених, помічників уповноважених тощо. Особливої уваги було приділено кадровим чисткам УНКВС на Одещині, які сягнули апогею після директиви ЦК ВКП(б) від 14 листопада 1938 р. «Про облік та перевірку в партійних органах відповідальних працівників НКВС СРСР», що скеровувало партійні комітети (міські, обласні, республіканські) на вжиття заходів на очищення органів НКВС від співробітників, які не заслуговували на політичну довіру. Зокрема, першочергово було направлено на розгляд ЦК ВКП(б) справи на 15 осіб керівного складу облуправління НКВС і 41 начальника районних відділів. Станом на 23 листопада Одеським обкомом КП(б)У було проведено ознайомчу роботу шляхом проведення бесід з 24 працівниками управління НКВС в Одеській області, сформувавши, відповідно, на них особисті справи. Із зазначеного числа через особливий сектор бюро обкому пройшло шість начальників відділів УНКВС i 18 начальників районних відділень. Перевірка виявила, разом з тим, значну кадрову некомплектність обласного УНКВС як серед керівного складу, так і на периферії, у районних відділеннях.

Автором зроблено висновки, що намагання керівництва ВКП(б) повернути контроль над НКВС, перебравши важелі кадрової політики на себе, застосовуючи своєрідну кадрову «санащію», просіюючи та відбраковуючи незручних, ненадійних, ідейно чужих тощо, призвели до майже иілковитого перезавантаження УНКВС в Одеській області. Поряд з тим, каральна функція НКВС не припинялась, активно здійснювалася й надалі. Пращівники управління НКВС в Одеській області як прихильні виконавиі волі правлячого режиму в СРСР, виокремлювалися переважною малограмотністю, робітничо-селянським соціальним походженням, політичною заангажованістю й ідейною відданістю.

Ключові слова: НКВС, Одеська область, Великий терор, кадрова політика, репресії

Пересилюючи нашу історію, наштовхуючись на ідеологічні рифи й історіографічні проблеми, викликані багаторічною атрофією колективної пам'яті, особливо у розрізі «незавершеності порахунків із комунізмом», маємо свідомо осягати те, що долати «власну історію» за висловом Я. Грицака, мусимо неодмінно опираючись на джерело - продукт і

\footnotetext{
* Михайлуца Микола Іванович - доктор історичних наук, професор, завідувач кафедри українознавства, історико-правових та мовних дисциплін Одеський національний морський університет (Одеса, Україна); ORCID: https://orcid.org/0000-0003-4896-0580; e-mail: Michailuca@ukr.net

${ }^{1}$ Розмови про Україну. Ярослав Грицак - Іза Хруслінська. Пер. 3 польської Богдани Матіяш. Київ: ДУХ I ЛІТЕРА, 2018. С 92.
} 
фіксатор комуністичної епохи, на документ, який обов'язково має бути підданий усебічному аналізу, без вживання та зловживання, очистки, вихолощення, заплямування, викривлення тощо. Оскільки «віра на слово», яке часто-густо виявляється напівправдою або гіпертрофованим міфом, закамуфльованою під правду брехнею тощо, здебільшого породжує цинізм, зневіру або нікчемний контраргумент у дискурсі наративів про Правду історії і часто генерує маніпулювання останньою й свідомістю необізнаних мас. Сучасне, збурене жагою до історичної справедливості, українському суспільству конче потрібує Правди, яка є гарантом й інструментом долання тяжкого історичного минулого.

Події останніх років, перетворення сутнісної ваги у державі та суспільстві (такі процеси спостерігалися й наприкінці 80-х - початку 90-х років минулого століття) вельми актуалізували проблематику історії комуністичного терору кінця 30-х років XX ст., знаного від Р. Конквеста як Великий терор, й, зокрема, ролі каральних органів (рос. ВЧК, ОГПУ, НКВД, НКГБ) у реалізації комуністичної доктрини більшовицького штибу в СРСР, і в УРСР. Не залишалися колеги-науковці у стороні від глибинного вивчення тем репресій на Півдні України, приміром і на Одещині. Тут виокремлюються фундаментальні видання з серії «Одеський Мартиролог», «Реабілітовані історією. Одеська область» ${ }^{2}$ а також низка наукових праць і дисертацій О. Бриндака, Г. Малинової, О. Сироти, Е. Петровського, О. Шишка й ін. Однак за об'єкт наукових досліджень переважно обиралися безпосередньо жертви терору на Одещині, а не палачі - працівники сталінських спецслужб.

Окремішню групу науковців представляють О. Бажан, О. Лошицький, В. Золотарьов регулярні автори-дописувачі історико-краєзнавчого наукового альманаху «Південний Захід. Одесика». Виразною рисою їхніх публікацій є глибокий аналіз біографій (за виразом авторів - «штрихів до портретів») виконавців політичної волі партійно-державного керівництва, зокрема, начальників Одеського обласного управління НКВС періоду 20-40-х років XX ст. У цьому напрямку заповнення специфічної наукової лакуни дослідниками плідно та регулярно здійснюється більше десяти років поспіль на сторінках зазначеного журналу під рубрикою «Край в епоху диктатур». Залишаючись вдячним колегам за колосальну науково-пошукову роботу по віднайденню та реконструкції пазлів життя (аж до біографічних дрібничок) головних палачів-виконавців на республіканському й обласному рівнях, все ж зазначимо, що поза увагою залишилися представники першої ланки, «низового ешелону» управлінь НКВС: співробітники районних відділів, оперуповноважені,

\footnotetext{
${ }^{2}$ Одеський мартиролог: дані про репресованих Одеси і Одеської області за роки радянської влади: іст.-мемор. вид. [у 4 т.] / уклад.: Л.В. Ковальчук, Г.О. Разумов. Одеса: ОКФА, 1997-2006. Т. 1. 1997.752 с.; Т. 2. 1999. 800 с.; Т. 3. 2005. 896 с.; Т. 4. 2006. 960 с.; Реабілітовані історією. Одеська область: Книга перша / Упорядники Л.В. Ковальчук, Е.П. Петровський. Одеса: АТ «ПЛАСКЕ», 2010. 800 с.

${ }_{3}^{3}$ Бажан О., Лошищький О. Апогей «великого терору на Одещині (1937-1938 рр.) // Південний-захід. Одесика: історико-краєзнавчий науковий альманах. Вип. 3. Одеса: «Орtimum», 2007. С. 163-174; Золотарьов В., Бажан 0. Свояк Сталіна. Сторінки біографії комісара Державної безпеки 1-го рангу Станіслава Реденса // Південний-захід. Одесика: історико-краєзнавчий науковий альманах. Вип. 5. Одеса: Друкарський дім, 2008. С. 132-161; Золотарьов В., Бажан О. Керівний склад УНКВС Одеської області доби «єжовщини» // Південнийзахід. Одесика: історико-краєзнавчий науковий альманах. Вип. 19. Одеса: Друкарський дім, 2015. С. 124-175; Золотарьов В., Бажан О. «В Одесі діти, які проживали неподалік облуправління, граючи між собою, кричали: «колись шпигун...»: Штрихи до портрета начальника УНКВС Одеської області Павла Кисельова // Південнийзахід. Одесика: історико-краєзнавчий науковий альманах. Вип. 23. Одеса: Друкарський дім, 2017. С. 121-141 та інші.
} 
помічники уповноважених тощо, часто безініціативні та послушні виконавці волі верхів. Ця категорія не менш цікава, хоча їх послужний список не такий вже і просторий за «заслугами перед тов. Сталіним і партією», у розкручуванні та викритті різних гучних «контрреволюційних зговорів, змов» тощо. Однак, саме ця категорія виконавців, як інструмент системи, на нашу думку, можуть бути важливим ілюстратором здійснення керівництвом ЦКВКП(б), місцевими партійними комітетами кадрового забезпечення місцевих управлінь НКВС, зокрема й наприкінці 1930-х років.

Нашу ж задачу бачимо у спробі проілюструвати на прикладі організаційно-партійної роботи Одеського обкому КП(б)У за посередництва партійного комітету управління НКВС в Одеській області кадрову «санацію» у сталінських спецслужбах, яка здійснювалася шляхом репресій працівників, вихолощення ії рядів, очищення від недостойних, ротації кадрів тощо.

Вельми актуальною, з огляду на мету та задачу дослідження, є презентація малознаної джерельної бази - фондів первинних партійних організацій колишніх «Партійних архівів обкомів КП(б)У» ${ }^{4}$. Значною частиною дослідників саме ця благодатна документальна база задля розуміння компартійного минулого, знехтувана через хибну думку колег про те, що евристизм цих матеріалів вичерпано, або й, що теж імовірно, через побоювання бути звинуваченими у політнекоректності, чи комуністичній заангажованості. Одне й інше є до міри помилковими позиціями, оскільки джерела й інформативні, й ілюстративні, і доказові. Підтвердженням цьому є наша стаття, присвячена соціо-структурному обрису одеської обласної парторганізації у роки Великого терору, що була опублікована раніше

Обмеживши наш інтерес періодом 1937-1939 рр., зосередимо увагу на тих справах, які зберігаються у Державному архіві Одеської області у фонді П-5355, опису 1 «ервинна організація КП(б)У Управління народного комісаріату внутрішніх справ - УНКВС в Одеській області (до липня 1934 р. Державного Політичного Управління - ДПУ), Сталінського району м. Одеси». Цей опис фіксує ще донедавна підгрифівські документальні матеріали зазначеної первинної парторганізації за період з 1929 по 1941 роки. У кількісних величинах справ не так вже й багато - всього 13, але важливою є їх інформативна складова. Переважно це постанови та директивні вказівки міського партійного комітету й Сталінського райкому КП(б)У (24 січня - 22 серпня 1938 р.), постанови й директивні вказівки Сталінського РК КП(б)У (4 лютого - 4 березня 1938 р.), протоколи партійних зборів УНКВС та УДБ УНКВС (3 січня - 28 грудня 1938 р.), протоколи засідань партійних бюро (29 квітня - 22 грудня 1938 р.), партійних комітетів відділів УНКВС та УДБ УНКВС (10 січня - 22 грудня 1938 р.), протоколи партійних зборів партгруп УНКВС, різноманітні виписки з протоколів міськпарткому (4 лютого 1938 р. - 27 січня 1939 р.), протоколи закритих партійних зборів партгрупи ХІ відділу УНКВС (26 грудня 1938 р.), листування 3 партійними органами та з органами НКВС по апеляційним справам (25 січня - 9 грудня 1938 р.) та інші.

\footnotetext{
${ }^{4} 27$ серпня 1991 р. Президія Верховної ради України ухвалила передати архіви компартії на державне зберігання, а партархіви структурно влилися до складу державних архівів. Законодавче закріплення відбулося 24 грудня 1993 р. $з$ прийняттям ВР України Закону «Про Національний архівний фонд і архівні установи».

${ }^{5}$ Михайлуца М. Одеська обласна більшовицька організація в роки Великого терору: чисельність, соціальний зріз, внутрішня боротьба і бюрократична волокити // Південний-захід. Одесика: історико-краєзнавчий науковий альманах. Вип. 22. Одеса: Друкарський дім, 2017. С. 121-135.
} 
Окрему групу документів складає опис 2 цього ж фонду, куди включено матеріали первинної організації КП(б)У Управління НКВС в Одеській області Сталінського району м. Одеси за 1922-1940рр. Переважно ці документи представлено протоколами бюро міському та Сталінського райкому про прийом у члени та кандидати ВКП(б) секретних співробітників ДПУ-НКВС, особисті справи на прийнятих у партію, серед них 81 персональна справа в алфавітному порядку (від Б до Я) та апеляційні справи на 130 осіб, також за алфавітом (А-Я), у хронологічних межах - 1935-1938 роки.

Аналізуючи перелік питань, які розглядалися IV-ю обласною партійною конференцією, пленумами та засіданнями бюро Одеського обкому КП(б)у у 1938 р., серед питань організаційного характеру, на кшталт прийому в партію, розгляд апеляційних справ, яких було вдосталь, про стан революційної законності у районах області, про партійно-масову роботу в МТС тощо, зауважимо, що важливої ваги для партійного керівництва набували саме питання кадрові. Зокрема, призначення на посади партійно-державної номенклатури обласного/районного рівнів, а також розгляд кандидатур для роботи в органи НКВС. Так, серед питань, що розглядалися на засіданні бюро Одеського обкому КП(б)У від 13 грудня 1938 р., із дев'яти пунктів порядку денного, сім було присвячено кадровим питанням: 6 затвердженню кандидатур на посади начальників райвідділів і відділу УДБ УНКВС в Одеській області, 1 - про звільнення від роботи начальника відділу кадрів обласного УНКВС. Зазначені матеріали, а саме протоколи №№ 57-66 засідань бюро обкому винятково у вигляді перших примірників, зосереджено у фонді П-11, оп. 1, спр. 13196. Нижня хронологічна межа датування документів відноситься до 29 листопада, а верхня - 17 грудня 1938 р. У цій справі зберігається протокольна інформація про затвердження начальників райвідділів: Мостовського РВ НКВС - Шумакова Івана Тимофійовича, Яновського РВ НКВС - Афоніна Івана Олексійовича, Карл-Лібкнехтовського РВ НКВС - Найденко Йосипа Григоровича, Гросулівського РВ НКВС - Хатнянського Степана Павловича ${ }^{7}$, Роздільнянського РВ НКВС - Громова-Юніна Олександра Дмитровича ${ }^{8}$, про затвердження заступником начальника 3-го (контррозвідувального) відділу УдБ УНКВС в Одеській області - Фомина Георгія Пилиповича', про затвердження начальниками ПісчаноБродського РВ НКВС - Ястребова Василя Михайловича, Савранського РВ НКВС - Бакулкіна Олександра Прокофійовича ${ }^{10}$, Хмелевського РВ НКВС - Фролова Василя Костянтиновича, Добровеличківського РВ НКВС - Дорожкіна Прокопія Олександровича, Голованівського РВ НКВС - Березинського Олексія Миколайовича ${ }^{11}$. Перелічені протоколи, на відміну від супровідних матеріалів, вирізняються вкрай обмеженою інформативністю, у них зазначалася лише сухі бюрократичні формулювання, номери партійних документів (партбілетів), стандартні резолюції з проханням до ЦК КП(б)У і ЦК ВКП(б) затвердити відповідні кандидатури. Усі ці протоколи підписано власноруч секретарем Одеського обкому КП(б)У Головіним.

\footnotetext{
${ }^{6}$ Держархів Одеської області (далі - ДАОО). Ф. П-11. Оп. 1. Спр. 1319. Протоколи засідань бюро обкому КП(б)У. 29 листопада - 17 грудня 1938 р. 204 арк.

${ }^{7}$ Ibid. Арк. 151.

${ }^{8}$ Ibid. Арк. 152.

${ }^{9}$ Ibid. Арк. 152.

${ }^{10}$ Ibid. Арк. 193.

${ }^{11}$ Ibid. Арк. 194.
} 
Наприкінці 1930-х рр. як безпосередня чекістська робота, так і поведінка пересічного службиста управління НКВС, у значній мірі члена/кандидата ВКП(б) чи комсомольця, регламентувалася не тільки розпорядчими документами й інструкціями центрального відомства, але й, зокрема, керівним органом партійної організації відділів Одеського управління НКВС - парткомом. Однак, самостійної поведінки від цих структур годі було й чекати. Основна й генеральна лінія визначалася, у першу чергу, рішеннями лютневоберезневого, липневого, серпневого 1937 р. та січневого 1938 р. пленумів ЦК ВКП(б) тощо.

Сліпу відданість генеральній лінії сталінського керівництва засвідчує резолюція до протоколу закритих зборів парторганізації відділів УНКВС за звітній період роботи (з 15 квітня 1937 р. по 19 квітня 1938 р.): «політична лінія парткому була правильною, робота задовільною. Парторганізація до перевиборів партійних органів прийшла ідеологічно здоровою, монолітною, міцно спаяною кругом ленінсько-сталінського ЦКВКП(б) і вождя народів тов. Сталіна» ${ }^{12}$. Попри таку риторику, слід усвідомлювати важливий фактор, який сприяв такій суцільній «монолітності» та впливав на поведінку переважаючої частки співробітників УНКВС - це різнобічний тиск з боку керівництва центральних органів НКВС, а також непохитна генеральна політична лінія Й. Сталіна і верхівки ВКП(б) на викорінення «ворогів народу», постійне «промивання мізків» на численних партійних зборах, у пресі тощо. До прикладу, у згаданий вище звітній період було проведено 31 засідання парткомітету та партзборів відділів Одеського обласного УНКВС, і що символічно й ілюстративно, із 24 партійних зборів - 20 були закритими. За цей же час партійним покаранням було піддано 13 осіб, з них: одному працівнику було поставлено на вид, п'ятьом винесено догани, семеро були виключені 3 партії ${ }^{13}$. А після виключення 3 партії, за технологією терору сталінської системи, зразу ж розпочиналось цькування, наставав арешт, фабрикувалася справа та виносився вирок. Саме за таким алгоритмом і здійснювалася, як свідчила шаблонізована фраза - «чистка засмічених ворогами народу органів».

Виключеними 3 партії та засудженими упродовж 1937-1938 рр. в УНКВС в Одеській області були Ніколаєвський, Тартаковський, Голобуцький, Саравайський, Мільцман, Карпачевський, Карасьов та інші ${ }^{14}$. В обговорюванні доповіді на закритих зборах від 23 березня 1938 р. працівник одеського управління А.І. Вутке зазначив: «За три скликання парткомітету управління НКВС в Одеській області нами виявлено до загальної кількості комуністів $10 \%$ ворогів народу» ${ }^{15}$. Не дарма тішився в.о. першого секретаря Одеського обкому КП(б)У, «старий чекіст і орденоносець, випробуваний в боротьбі 3 ворогами народу більшовик» Г.Г. Телешев, виголошуючи на IV-й обласній партконференції доповідь, пафосно вигукуючи: «Да здравствует советская разведка, которая под руководством Н.И. Ежова вскрывает и уничтожает вражеские гнезда. Ура!» ${ }^{16}$.

Кадрові санації та чистки особливо сягнули апогею після розсилки по управлінням НКВС від 14 листопада 1938 р. директиви ЦК ВКП(б) «Про облік та перевірку в партійних

\footnotetext{
${ }^{12}$ ДАОО. Ф. П-5355. Оп. 1. Спр. 118. Протоколи партзборів Одеського обласного управління НКВД за 1938 рік. Початок - 3 січня 1938 р. - закінчено 28 грудня 1938 р. Арк. 153.

${ }^{13}$ Ibid. Арк. 161-162.

${ }^{14}$ Ibid. Арк. 159.

${ }^{15}$ Ibid. Арк. 188.

${ }^{16}$ ДАОО. Ф. П-11. Оп. 1. Спр. 1250. Стенограма IV-ї обласної партійної конференції (том 4-й). 2 червня - 6 червня 1938 р. Арк. 135.
} 
органах відповідальних працівників НКВС СРСР», яка скеровувала партійні комітети (міські, обласні, республіканські) на вжиття заходів на очищення органів НКВС від співробітників, які не заслуговували на політичну довіру ${ }^{17}$. На думку О. Бажана, саме після санкціонованого комуністичним режимом документу розпочалися масові ротації як у керівництві апарату НКВС СРСР, так і в республіках та областях. Усуненими від керівництва відомством були не тільки М. Єжов і його оточення, але й переважно усі керівники республіканських, крайових та обласних управлінь $\mathrm{HKBC}^{18}$.

Яким чином спрацьовувала командно-адміністративна система у каральних структурах свідчить наступний перебіг подій і фактів. Телеграму за підписом Й. Сталіна про організацію обліку, перевірки та затвердження працівників НКВС в Одесі отримали 15 листопада 1938 р. і того ж дня її було розіслано для виконання усім секретарям районних партійних комітетів без винятку. Начальники районних відділів УНКВС, що мали проходити затвердження через партійні інстанції, перевірялися доволі розгорнутими характеристиками. Водночас, відділ керівних партійних органів (далі - ВКПО, рос. ОРПО) КП(б)У розпочав оформлення облікових документів й особистого ознайомлення 3 керівними посадовцями (працівниками) облуправління та районних відділень НКВС. У другій половині листопада 1938 р. вже було укладено персональні списки на зазначених посадовців НКВС, надано їм анкети для заповнення. Останні, до того ж, згодом перевірялися на предмет чесності та відкритості працівника перед партійними органами, унеможливлення приховування фактів виключення з партії, непролетарського соціального походження, нерадянської поведінки родичів тощо.

Про подробиці виконання спущеної зверху директиви секретар Одеського обкому КП(б)у Телешев невдовзі поінформував таємним листом завідувача відділом керівних органів ЦК ВКП(б) Г. Маленкова і, відповідно, заввідділом керівних органів ЦК КП(б) $\mathrm{y}^{19}$. Зокрема, першочергово передбачалося направити на розгляд ЦК ВКП(б) 15 осіб керівного складу облуправління НКВС і 41 начальника районних відділів. Станом на 23 листопада 1938 р. ВКПО Одеського обкому КП(б)У, який очолював Найдек, провело ознайомчу роботу шляхом проведення бесід 324 працівниками управління НКВС в Одеській області, сформувавши, відповідно, на них особисті справи. Із зазначеного числа через особливий сектор бюро обкому пройшло шість начальників відділів УНКВС і 18 начальників районних відділень $^{20}$. Перевірка виявила, разом 3 тим, значну кадрову некомплектність обласного УНКВС як серед керівного складу, так і на периферії, у районних відділеннях. Безпосередньо в обласному апараті бракувало шість працівників - у тому числі й начальник обласного управління НКВС, заступник начальника УНКВС і начальників морського відділу, 6-го відділу, 12-го відділу й особо-уповноважений УНКВС. Без очільників залишалися і 14 районних відділів УНКВС в Одеській області. Значною була кадрова ніша серед начальників відділків оперативних відділів, не вистачало оперативних

\footnotetext{
${ }^{17}$ Лубянка, Сталин и Главное управление госбезопасности НКВД. Архив Сталина. Документы высших органов партийной и государственной власти. 1937-1938. Москва, 2004. С. 606.

${ }^{18}$ Бажан О. Репресивна діяльність органів ВУНК-ДПУ-НКВС-КДБ на Київщині у 1919-1980-ті рр. // Реабілітовані історією. Київська область. Книга третя. Київ: Основа, 2011. С. 97-132.

${ }^{19}$ ДАОО. Ф. П-11. Оп. 1. Спр. 1349. Листування обкому КП(б)У з УДБ НКВС і областною міліщією про перевірку працівників партійних органів (на букви А-М). Початок січень1938 р. - закінчено грудень 1938 р. Арк. 141.

${ }^{20}$ Ibid. Арк. 142.
} 
уповноважень, помічників оперуповноважених як в обласному управлінні, так і в районах. Зачистка кадрів одеського управління НКВС спричинила некомплектність відділів, що визнавалося і самими партфункціонерами, як це, до прикладу, було під час розгляду характеристики претендента на посаду начальника 5-го відділку, зазначивши, що він «будучи висунутий на зазначену посаду з роботою не впорався через неукомплектованість штату».

Своєрідна «санація» кадрового складу каральних органів здійснювалася комуністичним режимом на чолі зі Й. Сталіним задля перезавантаження НКВС суцільно, так би мовити, у напрямку від центру до місць, «вичистити апарат органів від ворогів», які не мають політичної довіри, вихідців із соціально-чужого середовища, а також тих, хто не відповідав критеріям за своїми діловими здібностями. Серед тих, кого торкнулася така чистка наприкінці 1938 р., були відповідальні працівники одеського управління НКВС: начальник 11-го відділу УНКВС Каруцький Семен Абрамович (ст. л-т д/б, член ВКП(б) з 1930 р., чекіст 31920 р.), Рибаков Йосип Єфимович (л-т д/б, член ВКП(б) з 1937 р р.), начальник відділу кадрів УНКВС в Одеській області Дубров Іван Степанович (ст.л-т д/б, член ВКП(б) 31920 р., чекіст 3 1920 р.), начальник Благоївського районного відділу НКВС Маслов Олександр Сергійович

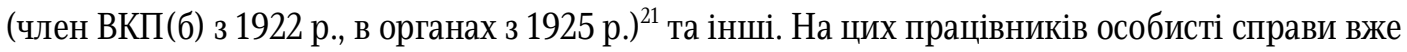
перебували у відділі кадрів республіканського НКВС у Києві, що дає нам можливість стверджувати, що вони вже перебували у розробці по санкціонованим зверху та фабрикованим справам на «ворогів у чекістських рядах».

Секретар Одеського обкому Телешев запевняюче інформував керівництво ВКП(б) про цілковиту підтримку колективом УНКВС постанови ЦК про облік і перевірку кадрів УДБ, яка на його думку, «знайшла гаряче відлуння серед оперативних працівників». Оскільки раніше кадрові питання вирішувались винятково відомчим керівництвом, яке у 1930-х роках припускалося низки «помилок», переважно суб'єктивного характеру, цілком зрозуміло, що керівна партійна еліта, посилаючись на необхідності об'єктивної оцінки роботи кожного чекіста, намагалися, у першу чергу, контролювати каральні органи, які дедалі ставали над партійними структурами ВКП(б). Тепер, наприкінці 1938 р. останні намагалися виправити ситуацію на свою користь. У всякому разі, тут цілком слушно звучать зауваги відомого українського науковця С. Кульчицького стосовно того, що «органи насилля у вигляді ВЧКОДПУ-УДБ-НКВС були безпосереднім продовженням партійних структур» ${ }^{22}$.

Яскравим прикладом перезавантаження кадрів обласних управлінь шляхом перекидання середньої ланки в межах республіки і СРСР, зокрема начальників відділів і відділків як перспективних уповноважених, є свідчення секретаря партбюро УДБ НКВС в Одеській області Дубового, яке він виклав у звітній доповіді на партійних зборах управління кількома місяцями пізніше, у липні 1939 р. Стосовно плинності кадрів за попередній 1938 рік партійний функціонер зазначив, що станом на грудень 1938 р. партійна організація УНКВС в Одеській області повністю оновилася, оскільки 130 осіб знялися 3 обліку, переважно у зв'язку з переведенням в інші місця роботи, а прийнято було 159 осіб, що суттєво впливало на негативні результати в роботі колективу ${ }^{23}$. Проте за жодним словом

\footnotetext{
${ }^{21}$ Ibid. Арк. 143-145.

${ }^{22}$ Кульчищький C. Методи роботи ДПУ уСРР та відображення їх у службовій документації // Архівно-слідчі справи репресованих: науково-методичні аспекти використання : зб. наук. праць. Київ, 1998. С. 14.

${ }^{23}$ ДАОО. Ф. П-11. Оп. 1. Спр. 136. Протоколи засідань партійного бюро УНКВС. Початок 4 квітня 1939 р. закінчено 26 липня 1939 р. Арк. 17.
} 
Дубового не констатувалися інші причини, серед яких чільне місце займали репресії та звільнення з органів за «порушення соціалістичної законності, незаконні методи ведення слідства, фальсифікацію справ на репресованих працівників НКВС» тощо. Однак, лише у 1938 р. хвиля «ворогоманії» та «шпигуноманії» вдарила по самому апарату НКВС УРСР, у результаті чого було заарештовано 261 «зрадника», «учасника правотроцькістської організації» й інших «антирадянських формувань», «шпигунів» тощо. А загалом у республіці 1938 р. було ув'язнено 994 співробітника $\mathrm{HKBC}^{24}$, у тому числі і в Одеській області було репресовано 41 працівника ${ }^{25}$.

Чистка в органах НКВС після арешту М. Єжова, яку з листопада 1938 р. очолив Л. Берія, призвела до поповнення лав новими кадрами. Найпереконливішими критеріями по відбору працівників вважалися: надійне соціальне походження, партійний стаж i незаплямована відданість ВКП(б) діями, що підтверджувалося відповідними характеристиками. Натомість, значна частка нових працівників, яка наприкінці 1938 р. були мобілізована до органів НКВС в Одеській області, мала дуже низький освітній рівень, що виглядає вкрай контроверсивно, враховуючи службові «заслуги». До прикладу, у грудні 1938 р. було затверджено на посаду заступника начальника 3-го відділу облуправління НКВС колишнього начальника РВ Зельцького (німецького національного району) Одеської області Г.П. Фоміна, який хоч і мав нижчу освіту, проте був із селян-бідняків. Однак, як зазначалося у характеристиці: «Фомін... ініціативний, має низку позитивних результатів по викриттю фашистських формувань у Зельцькому районі. <..> За особистими якостями, може бути висунутий на більш відповідальну керівну чекістську роботу» ${ }^{26}$. Що, власне, позитивно вирішило його кар'єрне призначення. Аналогічна ситуація була й з іншими одеськими чекістами. 3 незакінченою середньою освітою пройшли спецперевірку особливим сектором Одеського обкому КП(б)У й обласного управління НКВС: молодший лейтенант д/б I.T. Шумаков, мобілізований до органів 3 комсомольської роботи ${ }^{27}$; із селян-бідняків 3 нижчою освітою сержант д/б Й.Г. Найденко, який, до того ж, за розпорядженням заступника наркома УРСР був арештований на 5 діб за «ряд неетичних вчинків» ${ }^{28}$.

Попри негативну послужну характеристику просувався по кар'єрних сходах колишній робітник металургійного заводу І.О.Афонін ${ }^{29}$. Йому закидали грубість і схильність до неадекватної поведінки. Із стандартно-шаблонної атестації на молодшого лейтенанта д/б I.О. Афоніна дізнаємося, що він «чекістську роботу знає слабо, може використовуватися тільки під керівництвом», що мав догану за «грубе ставлення не тільки до підслідних, але й до членів партії, попри це його таки рекомендували у грудні 1938 р. на посаду начальника райвідділу НКВС, за умови «надання облуправлінням НКВС у його роботі повсякденної допомоги» ${ }^{30}$.

Найбілыш відомі своєю жорстокістю та незаконними методами ведення слідства працівники УНКВС в Одеській області упродовж 1937-1938 років як правило вирізнялися

\footnotetext{
${ }^{24}$ Великий терор 1937-1938 pp. URL: http://www.territoryterror.org.ua/uk/history/1919-1939/ussr/srsr8/

${ }^{25}$ Одеський мартиролог... Т. 1. 1997. С. 677.

${ }^{26}$ ДАОО. Ф. П-11. Оп. 1. Спр. 1323. Матеріали до протоколів № 64-66 засідань бюро обкому КП(б)У. Початок 13 грудня 1938 р. - закінчено 17 грудня 1938 р. Арк. 59-60.

${ }^{27}$ Ibid. Арк. 49.

${ }^{28}$ Ibid. Арк. 54.

${ }^{29}$ Ibid. Арк. 51.

${ }^{30}$ Ibid. Арк. 52.
} 
малограмотністю, невіглаством, неуцтвом. Так, тимчасово виконуючі обов'язки начальники (оскільки часто змінювалися) 1-го відділку 2-го відділу сержант д/б Кордун Д.Б. (з 1932 р. в органах НКВС) мав нижчу освіту; сержант д/б Є.І. Абрамович в органах з 1938 р., мав нижчу освіту; політрук Я.І. Берензон в НКВС з 1934 р., мав нижчу освіту; начальник 3-го відділку 2-го відділу В.А. Мошковський в органах 31937 р. мав неповну середню освіту, оперуповноважений 1-го відділку 2-го відділення УНКВС сержант д/б А.Є. Гнєсін (в органах 31938 р.) мав теж неповну середню освіту ${ }^{31}$. Як «слабкий і нездатний працівник» характеризувався начальник відділу кадрів управління НКВС в Одеській області старший лейтенант д/б І.С. Дубров (в органах ВНК-ОДПУ-НКВС з 1920 р.), який до того ж, вирізнявся склочним характером і лицемірством, через що авторитетом серед колег не користувався ${ }^{32}$. Навіть першим заступником секретаря партбюро УНКВС в Одеській області було обрано П.І. Дейнегу, начальника відділення економвідділу УНКВС, що мав також незакінчену середню освіту ${ }^{33}$. Та що там говорити, коли перший ешелон лідерів революції - В. Ленін, Ф. Дзержинський, Й. Сталін та ін. не мали закінченої вищої освіти. А в низах загалом ситуація була катастрофічною, що не могло не відбиватись на професіоналізмі працівників i, головно, на людських якостях. У виступі парторга спецпідрозділу УДБ НКВС Арсеньєва, доріканням прозвучало, що у 3-му спецвідділі є люди, які пропрацювали по 7-10 років, але не висовувалися на підвищення по роботі, через недостатню грамотність. Кількаразово ставилося питання про організацію при спецпідрозділі загальноосвітньої школи, але через брак коштів це питання не вирішувалося ${ }^{34}$.

У першій декаді березня 1939 р. на засіданні бюро Одеського обкому КП(б) ${ }^{35}$ було розглянуто та спрямовано на затвердження в ЦККП(б)у і ЦКВКП(б) додатково кандидатури начальників районних відділень НКВС: Хмелевського району - Фролов В.К., Піщано-Бродського району - Ястребов В.М., Роздільнянського району - ГромоваЮніна О.Д., Гросулівського району - Хатнянського С.П., Голованівського району Березинського О.М. та ін. Лави борців з «ворогами народу» поповнювалися нескінченно.

Отже, вельми репрезентативна джерельна база, що зберігається у партійних фондах ДАОО надає можливість якомога глибше дослідити процеси кадрової політики в обласних управліннях НКВС, на прикладі Одеського УНКВС простежити процеси службової ротації, кадрової чистки таперезавантаження місцевих і регіональних спецслужб після листопада 1938 р. $з$ приходом до керівництва наркомату Л. Берії. Намагання керівництва ВКП(б) повернути контроль над НКВС, перебравши важелі кадрової політики на себе,

\footnotetext{
${ }^{31}$ Архів СБУ в Одеській області. Фонд «П». Спр. 10175-п «По звинуваченню учасників контрреволюційної фашистської організації: Деньга Ф.К., Андріанова О.Є., Рожновського М.М., Івлєва П.Г., Папе Д.М., Сорокіна І.І., Жирова К.Д. по ст. 54-6, 54-10 ч. 1, 54-11 КК УРСР». Початок 23 квітня 1938 - закінчено 5 травня 1938 р. Арк. 324-325;

32 ДАОО. Ф. П-5355. Оп. 1. Спр. 118. Протоколи партзборів Одеського обласного управління НКВД за 1938 рік. Початок - 3 січня 1938 р. - закінчено 28 грудня 1938 р. Арк. 63.

33 ДАОО. Ф. П-5355. Оп. 1. Спр. 135. Протоколи засідання партбюро УНКВД в Одеській області. Початок 17 липня 1939 р. закінчено - 10 жовтня 1939 р. Арк. 43.

${ }^{34}$ ДАОО. Ф. П-5355. Оп. 1. Спр. 134. Протокол засідання парткомітету уГБ уНКВД в Одеській області від 4 лютого 1939 р. Протоколи засідань парткомітету УГБ УНКВД. Початок 14 лютого 1939 р. - закінчено 16 березня 1939 р. Арк. 25.

${ }^{35}$ ДАОО. Ф. П-11. ОП. 1. Спр. 1446. Протоколи №№ 105-111 засідань бюро обкому КП(б)У (1-й примірник). Початок 3 березня 1939 р. - закінчено 10 березня 1939 р. Арк. 72.
} 
застосовуючи своєрідну кадрову «санацію», просіюючи та відбраковуючи незручних, ненадійних, ідейно чужих тощо, призвели до майже цілковитого перезавантаження органів НКВС. Поряд 3 тим, каральна функція останніх не припинялась, активно здійснювалася й надалі. Працівники управління НКВС в Одеській області, як прихильні виконавці волі правлячого режиму в СРСР, виокремлювалися переважною малограмотністю, робітничоселянським соціальним походженням, політичною заангажованістю й ідейною відданістю.

\section{Mykola Mykhailutsa}

\section{Personnel Authority of People's Commissariat of Internal Affairs in the Odessa Region During the Time of Great Terror}

Abstract: The article refers to personnel policy of the Communist Party of Soviet Union (CPSU) as a part of the People's Commissariat of Internal Affairs (NKVD) connected with Ukrainian People's Commissariat of Internal Affairs (UNKVD) in the late 1930s. The research is based on party sources of State Archive of the Odessa region. This study is related to representatives of higher and lower position in administration of NKVD: officials of district department, security officers, assistants, etc. Special attention was paid to separation of staff in UNKVD of Odessa. It reached a critical point after the Communist Party Central Committee's directive of 14 November 1938 «About the party's registration and verification of executive employees of NKVD of the USSR»; they organized party's committees (urban, regional, and republican) to clear the NKVD from employees, who are not trustworthy. Firstly, the cases of 15 officials of leadership team of local government and 41 directors of district division were considering. Also on November 23, Regional Committee of Communist Party interviewed 24 administrators and created their personnel files. Since that date, 6 directors of departments of NKVD and 18 directors of district departments went through special section of Regional Committee. The inspection found large staffing shortage among leadership team and in district divisions.

The author reached the conclusion that CPSU's efforts to regain control of NKVD through implementation of staffing policy, taking out unreliable, ideologically different people. They almost reset UNKVD in the Odessa region. However, its punitive function did not stop. NKVD's employees allocated by their poor education, peasant origin, politicking and idealism.

Keywords: the People's Commissariat of Internal Affairs (NKVD), the Odessa region, the Great Terror, personnel policy, repression 